\title{
Komposisi Unsur Hara Kompos yang Dibuat dengan Bantuan Agen Dekomposer Limbah Bioetanol pada Level yang Berbeda
}

\author{
R. A. Bachtiar, M. Rifki, Y. R. Nurhayat, S. Wulandari, R. A. Kutsiadi, A. Hanifa, M. Cahyadi* \\ Program Studi Peternakan, Fakultas Pertanian, Universitas Sebelas Maret, Surakarta, Indonesia 57126
}

\begin{abstract}
ABSTRAK
Penelitian ini bertujuan mengevaluasi pengaruh level penggunaan dekomposer limbah bioetanol terhadap kandungan unsur hara pupuk kompos. Materi penelitian yang digunakan adalah feses sapi peranakan Fresian Holstein (PFH) jantan, berumur 3-5 tahun sebanyak 6 ekor dan dekomposer limbah bioetanol. Rancangan penelitian menggunakan rancangan acak lengkap pola searah dengan empat perlakuan dan enam ulangan. Kompos dibuat menggunakan sampel feses sebanyak $4 \mathrm{~kg}$ dengan level penggunaan dekomposer masing-masing sebesar 0,$4 ; 0,5 ; 0,6$ dan $0,7 \%$. Analisis kualitas kimia pupuk kompos di Laboratorium Kimia dan Kesuburan Tanah Program Studi Ilmu Tanah Fakultas Pertanian Universitas Gajah Mada Yogyakarta. Analisis data dilakukan menggunakan software Minitab 17. Hasil analisis variansi penelitian menunjukkan bahwa penggunaan perbedaan level dekomposer berpengaruh terhadap unsur hara karbon $(\mathrm{C})$, fosfor $(\mathrm{P})$, kalium $(\mathrm{K})$ dan magnesium $(\mathrm{Mg})(\mathrm{P}<0,05)$ Kandungan $\mathrm{C}$ organik, $\mathrm{P}, \mathrm{K}$, dan $\mathrm{Mg}$ tertinggi ditemukan pada perlakuan $\mathrm{P}$ 2, di sisi lain kandungan $\mathrm{N}, \mathrm{Ca}$, rasio $\mathrm{C} / \mathrm{N}$ nilai $\mathrm{pH}$ dan suhu kompos tidak terdapat perbedaan antar perlakuan. Kesimpulan penelitian ini adalah pembuatan pupuk kompos dengan bioaktivator terbaik pada konsentrasi P2 (0,5\%).
\end{abstract}

Kata kunci: Dekomposer, Kompos, Limbah bioetanol, Unsur hara

\section{Nutrient Contents of Compost Made with Different Level of Decomposer Agent from Processed Bioethanol Waste}

\begin{abstract}
The objective of research was to evaluate the effect of different level of decomposers from bioethanol waste as a bioactivator to compost nutrient content. The materials used in this study were feces collected from 6 bulls of 3 to 5 years old of Fresian Holstein (PFH), and decomposer agents from processed-bioethanol waste. The experimental design used was completely randomized design with four treatments and six replications. Compost was made using $4 \mathrm{~kg}$ of feces with the levels of processed-bioethanol waste were 0.4, 0.5, 0.6, and 0.7\%, respectively. Analysis of nutrient contents of compost was conducted at the the Laboratory of Chemistry and Soil Fertility, Department of Soil Science, Faculty of Agriculture, Gajah Mada University, Yogyakarta. Data analysis was performed using Minitab 17 software. The results of the analysis of variance showed that different levels of decomposer affected organic C, phosphor (P), Kalium (K), and Magnesium (Mg). Organic C, $P$, $K$, and $M g$ contents were found highest in $P 2$, on the other hand $N$ and Ca contents, C/N ratio, $p H$, and temperature of compost were not different among treatments. It could be concluded that compost made with $0.5 \%$ decomposer agents from processedbioethanol waste was the best.
\end{abstract}

Keywords: Bioethanol waste, Compost, Decomposer, Nutrient content

\section{PENDAHULUAN}

Penggunaan agen dekomposer pada zaman sekarang sudah banyak dikenal dan sangat membantu khususnya dalam penanggulangan limbah peternakan di masyarakat. Peternakan memiliki peran pokok sebagai penggerak ekonomi nasional dalam menciptakan kebutuhan pokok pangan dan gizi. Peran peternakan disamping sebagai penyedia kebutuhan protein hewani usaha peternakan menghasilkan limbah yang berpotensi sebagai sumber pencemaran lingkungan. Salah satu pengelolaan limbah yang dapat dimanfaatkan adalah menjadi pupuk kompos (Subagyo, 2008). Pupuk kompos adalah hasil dari pelapukan bahan-bahan dari kotoran ternak, sisa makanan ternak dan lain sebagainya (Ginting, 2007).

Kompos merupakan pupuk yang berasal dari sisasisa bahan organik yang dapat memperbaiki sifat fisik dan struktur tanah, meningkatkan daya menahan air,

*Penulis Korespondensi: Muhammad Cahyadi

Alamat: J1. Ir. Sutami 36A Kentingan, Jawa Tengah 57126

E-mail:mcahyadi@uns.ac.id kimia tanah dan biologi tanah (Rukmana, 2007). Prinsip teknologi pengomposan merupakan peniruan proses terbentuknya humus oleh alam dengan bantuan mikroorganisme. Proses pengomposan secara alami memerlukan waktu yang sangat lama, pengomposan dapat berlangsung secara aerob dan anaerob dengan bantuan bioaktivator sehingga dapat berjalan dalam waktu yang lebih cepat (Kesumaningwati, 2015).

Bioaktivator adalah bahan aktif biologi yang digunakan untuk meningkatkan aktivitas proses komposting (Wahyono et al, 2003). Penggunaan bioaktivator dalam pembuatan kompos berpengaruh dalam hal penyediaan unsur hara di dalamnya. Jenis mikroorganisme yang ada dalam bioaktivator dapat mempengaruhi kandungan zat kimia dalam pupuk kompos yang dihasilkan. Proses kecepatan pengomposan tidak hanya ditentukan oleh kelimpahan mikroorganisme tapi juga ditentukan oleh jumlah bahan yang dikomposkan (Triwibowo, 2015).

Pembuatan bioaktivator dapat dilakukan dengan menggunakan berbagai media yang mengandung senyawa karbohidrat sebagai contoh limbah bioetanol. 
Pertumbuhan konsumsi bioetanol sebagai salah satu energi terbaharukan di dunia mengalami pertumbuhan pesat dalam kurun waktu beberapa tahun terakhir. Pertumbuhan tersebut semakin meningkat dikarenakan banyaknya negara di dunia yang mendorong penggunaan bioetanol sebagai bahan bakar. Meningkatnya kebuthan bioetanol otomatis semakin banyak limbah bioetanol yang di hasilkan. Soeprijanto et al. (2010) melaporkan bahwa air limbah bioetanol mengandung senyawa garam, gula, karbohidrat, mineral dan unsur lain yang tersuspensi maupun terlarut dalam air. Limbah cair industri bioetanol masih bisa dimanfaatkan karena mengandung karbohidrat, asam dan zat organik lainya yang masih cukup tinggi (Nurcahyani dan Utami, 2015). Keberadaan industri bioetanol ini sangat membantu masyarakat dalam menyediakan lapangan pekerjaan., dalam satu hari dapat memproduksi sebanyak 1000-2000 liter/hari dengan limbah yang dihasilkan sebanyak 7000-8000 liter/hari (Agus dan Widianto, 2004). Limbah industri bioetanol apabila tidak dimanfaatkan akan menimbulkan pencemaran lingkungan khususnya lahan pertanian.

Bioaktivator sangat membantu mengefisienkan proses pengomposan, digunakan bioaktivator effective microorganisms (em-4) sebanyak 0,25\% sampai 0,5\% dari total bahan baku feses (Bahar dan Haryanto, 2000) Marlinda (2015) sebanyak 0,7\% bioaktivator dari bahan utama sampah organik rumah tangga yang digunakkan memiliki nilai karbon (C) organik paling optimal. Penelitian sebelumnya menggunakan bioaktivator limbah bioetanol sebanyak $0,5 \%$ dari bobot feses yang digunakkan dibandingkan dengan bioaktivator produk komersil sebagai agen dekomposer memiliki performa yang sama (Alfadli, 2018). Penggunaan level yang tepat diperlukan agar efektifitas bakteri bekerja sesuai kapasistasnya. Berdasarkan uraian diatas perlu dilakukan penelitian tentang pengaruh level bioaktivator limbah bioetanol terhadap kualitas unsur hara pupuk kompos.

\section{MATERI DAN METODE}

\section{Pembuatan Kompos}

Proses pembuatan kompos dimulai dengan koleksi feses sapi dari bangsa Peranakan Friesian Holstein (PFH) jantan berumur 3-5 tahun sebanyak 6 ekor yang dilakukan selama 1 hari, dimana setiap ekor sapi menghasilkan sebanyak 18-20 kg feses segar. Feses yang telah dikumpulkan, kemudian diamkan selama 3 hari untuk menurunkan kadar air. Bioaktivator dalam pembuatan kompos ini adalah bioaktivator limbah bioetanol yang menggunakan air dan molasses sebagai campuran dengan perbandingan 1:1:1 (Alfadlli et al., 2018). Penggunaan level campuran bioaktivator limbah bioetanol sesuai yang dilakukan oleh Bahar dan Haryanto (2000) yaitu $0,5 \%$ dari bobot feses (v/w) dan Marlinda (2015) yaitu $0,7 \%$ dari bobot feses (v/w) serta diambil batas bawah sebanyak satu poin pada masingmasing konsentrasi.

Feses ditimbang sebanyak $96 \mathrm{~kg}$ dan masingmasing $24 \mathrm{~kg}$ feses digunakan untuk setiap perlakuan. Penambahan bioaktivator berupa campuran bioaktivator limbah bioetanol dilakukan dengan cara disemprotkan berdasarkan perlakuan pada setiap feses. Selanjutnya, campuran bahan tersebut yang telah disesuaikan dengan tiap perlakuan dihomogenkan dan dimasukkan dalam toples penampung sebanyak $4 \mathrm{~kg}$ sehingga menjadi 6 ulangan pada setiap perlakuan. Kompos disimpan selama 28 hari didalam toples dengan keadaan tertutup agar terjadi proses pengkomposan dengan memanfaatkan mikroba

Tabel 1. Kandungan bioaktivator yang digunakan

\begin{tabular}{|c|c|c|}
\hline No & Unsur Hara dan mikroorganisme & Kadar dalam PLB ${ }^{1}$ \\
\hline 1 & $\mathrm{BPF}$ & $2,3 \times 10^{5}$ \\
\hline 2 & Lactobacillus $S p$ & $4,9 \times 10^{7}$ \\
\hline 3 & Yeast & $3,9 \times 10^{7}$ \\
\hline 4 & Actinomycetes & + \\
\hline 5 & Bakteri fotosintetik & + \\
\hline 6 & E.Coli & - \\
\hline 7 & Salmonella & - \\
\hline 8 & $\mathrm{P}_{2} \mathrm{O}_{5}$ & $0,59 \%$ \\
\hline 9 & $\mathrm{~K}_{2} \mathrm{O}_{5}$ & $1,26 \%$ \\
\hline 10 & $\mathrm{Ca}$ & $0,08 \%$ \\
\hline 11 & $\mathrm{Ph}$ & 4,55 \\
\hline 12 & Protein & $11,025 \%$ \\
\hline 13 & Lemak & $7,465 \%$ \\
\hline 14 & C-Organik & $31,17 \%$ \\
\hline 15 & Bahan Organik & $53,74 \%$ \\
\hline 16 & $\mathrm{~N}$ & $0,52 \% \%$ \\
\hline 17 & $\mathrm{Mg}$ & 0,15 \\
\hline 18 & C/N Ratio & $59,94 \%$ \\
\hline
\end{tabular}


fakultatif serta diletakkan di tempat yang teduh dan terhindar dari hujan dan panas. Perkembangan pada suhu dan nilai $\mathrm{pH}$ dilakukan pengamatan setiap 3 hari sekali pada sore hari (Alfadli et al., 2018). Pengamatan terhadap kompos juga dilakukan guna mengontrol laju pengomposan dengan memperhatikan kelembapan kompos agar proses pengomposan berjalan lancar. Pembalikan kompos dilakukan setiap 7 hari sekali guna memperlancar sistem aerasi .

\section{Analisis Unsur Hara Kompos}

Data yang dianalisis meliputi C organik, Nitrogen, rasio $\mathrm{C} / \mathrm{N}$, Fosfor, Kalium, Kalsium dan Magnesium menggunakan prosedural teknis Balai Penelitian Tanah (2009). Kandungan C dan N dianalisis menggunakan analisis proksimat, kandungan fosfor ditentukan menggunakan Spektrofotometer (Spectronic, USA), kandungan Kalium dianalisis menggunakan Flamephotometer (Jenway, UK), serta kandungan Kalsium dan Magnesiuam ditentukan menggunakan prosedur standar untuk Atomic Absorption Spectrophotometer (Merck, USA) yang dilakukan di Laboratorium Kimia dan Kesuburan Tanah, Fakultas Pertanian, Universitas Gadjah Mada. Rasio C/N dihitung dengan membandingkan nilai $\mathrm{C}$ organik dan kandungan Nitrogen yang dinyatakan dalam persen (\%). Nilai $\mathrm{pH}$ diukur menggunakan $\mathrm{pH}$ meter digital dan suhu kompos juga diukur menggunakan termometer digital.

\section{Rancangan Percobaan dan Analisis Data}

Metode yang digunakan dalam penelitian ini dilakukan menurut Bahar dan Haryanto (2000) yaitu, menggunakan rancangan acak lengkap pola searah, dengan 4 perlakuan dan 6 kali ulangan. Setiap perlakuan menggunakan starter bioaktivator limbah bioetanol dengan level berbeda. Adapun perlakuan yang digunakan adalah sebagai berikut:

- P1: feses sapi dengan tambahan bioaktivator limbah bioetanol 0,4\%

- P2: feses sapi dengan tambahan bioaktivator limbah bioetanol $0,5 \%$

- P3: feses sapi dengan tambahan bioaktivator limbah bioetanol $0,6 \%$
- P4: feses sapi dengan tambahan bioaktivator limbah bioetanol $0,7 \%$

Data yang diperoleh dalam penelitian ini dianalisis menggunakan analisis variansi (analysis of variance/ANOVA). Apabila terdapat perbedaan yang nyata antar perlakuan, maka akan dilanjutkan dengan Tukey (Steel and Torrie, 1993). Model matematika yang digunakan dalam penelitian ini yaitu:

$$
\mathrm{Y}_{\mathrm{ij}}=\mu+\mathrm{t}_{\mathrm{i}}+\varepsilon_{\mathrm{ij}}
$$

$\mathrm{Y}$ adalah nilai pengamatan perlakuan ke-i dan ulangan ke-j, $\mu$ adalah nilai tengah, $t_{i}$ adalah pengaruh perlakuan ke-i, dan $\varepsilon_{\mathrm{ij}}$ adalah galat percobaan pada perlakuan ke-i dan ulangan ke-j.

\section{HASIL DAN PEMBAHASAN}

\section{Nilai pH dan Suhu}

Hasil analisis statistik penggunaan perbedaan level bioaktivator tidak berbeda nyata terhadap nilai $\mathrm{pH}$ kompos, pengomposan selama 28 hari diperoleh nilai ph kompos sebesar 7,20 sampai 7,36 (Tabel 2). Pada level P1 hingga P4 menunjukkan dalam kategori netral, standar kualitas kompos dari parameter $\mathrm{pH}$ menurut SNI (2004) mendekati batas maksimal sebesar 7,49. Hal ini disebabkan penggunaan metode anaerob selama proses pengomposan berlangsung menghasilkan uap air yang tertahan di dalamnya sehingga kelembaban bertambah. Menurut Manser (2008) pori-pori tumpukan bahan kompos yang terisi air cenderung menimbulkan kondisi anaerobik dan kinerja mikroba tidak dapat berkembang mencapai $\mathrm{pH}$ netral. Pernyataan diatas sesuai dengan Hanafiah (2005) Kelembaban berperan penting dalam proses dekomoposisi. Pada kelembaban yang yang rendah jamur atau bakteri dapat bekerja lebih aktif.

Hasil analisis statistik penggunaan perbedaan level bioaktivator tidak mempengaruhi nilai suhu kompos. Hal ini diduga pengaruh bioaktivator terhadap proses pendinginan dan pematangan dalam pengkomposan memiliki kecepatan yang sama. Suhu pengomposan selama 28 hari sebesar $29,40^{\circ} \mathrm{C}$ hingga $29,63^{\circ} \mathrm{C}$ (Tabel 2), standar kualitas kompos dari parameter suhu menurut SNI (2004) mendekati batas

Tabel 2. Kandungan unsur hara pupuk kompos dengan penambahan level dekomposer yang berbeda

\begin{tabular}{lccccc}
\hline \multirow{2}{*}{ Peubah } & \multicolumn{4}{c}{ Perlakuan } & \multirow{2}{*}{ Nilai P } \\
\cline { 2 - 5 } & P1 & P2 & P3 & P4 \\
\hline C Organik & $43,08 \pm 0,20^{\mathrm{b}}$ & $43,86 \pm 0,50^{\mathrm{a}}$ & $42,92 \pm 0,56^{\mathrm{b}}$ & $43,42 \pm 0,51^{\mathrm{ab}}$ & 0,01 \\
N Total & $1,60 \pm 0,13$ & $1,76 \pm 0,38$ & $1,67 \pm 0,18$ & $1,99 \pm 0,72$ & 0,44 \\
P Total & $0,33 \pm 0,02^{\mathrm{a}}$ & $0,37 \pm 0,02^{\mathrm{a}}$ & $0,21 \pm 0,04^{\mathrm{b}}$ & $0,25 \pm 0,03^{\mathrm{b}}$ & 0,00 \\
K Total & $1,15 \pm 0,05^{\mathrm{ab}}$ & $1,24 \pm 0,09^{\mathrm{a}}$ & $1,24 \pm 0,07^{\mathrm{a}}$ & $1,10 \pm 0,04^{\mathrm{b}}$ & 0,01 \\
Rasio C/N & $26,95 \pm 2,45$ & $26,36 \pm 8,25$ & $25,99 \pm 3,07$ & $23,54 \pm 5,87$ & 0,71 \\
Ca Total & $0,55 \pm 0,07$ & $0,51 \pm 0,09$ & $0,48 \pm 0,05$ & $0,48 \pm 0,05$ & 0,30 \\
Mg Total & $0,19 \pm 0,01^{\mathrm{b}}$ & $0,29 \pm 0,05^{\mathrm{a}}$ & $0,21 \pm 0,05^{\mathrm{ab}}$ & $0,21 \pm 0,07^{\mathrm{ab}}$ & 0,02 \\
pH & $7,20 \pm 0,22$ & $7,33 \pm 0,12$ & $7,28 \pm 0,13$ & $7,36 \pm 0,17$ & 0,37 \\
Suhu & $29,63 \pm 0,24$ & $29,40 \pm 0,37$ & $29,41 \pm 0,36$ & $29,56 \pm 0,40$ & 0,60 \\
\hline Keter & & &
\end{tabular}


maksimal suhu tanah yaitu sebesar $30^{\circ} \mathrm{C}$. Hasil yang diperoleh sependapat dengan Yuliarti dan Isroi (2009), panas dihasilkan dari aktifitas mikroba berhubungan langsung antara peningkatan suhu dengan konsumsi oksigen. Temperatur berkisar antara $30-60^{\circ} \mathrm{C}$ menunjukkan aktifitas pengomposan yang cepat. Aktifitas peningkatan suhu dengan waktu singkat untuk mempercepat disebabkan dari starter yang digunakan dalam pengkomposan.

\section{Kadar Karbon (C) Organik}

Hasil penelitian menunjukkan bahwa perbedaan level bioaktivator terhadap unsur hara pupuk kompos $\mathrm{C}$ Organik sangat berbeda nyata $(\mathrm{P}<0,01)($ Tabel 2$)$. Hasil analisis uji lanjut diperoleh hasil P1 dan P3 dibandingkan dengan $\mathrm{P} 2$ memiliki nilai berbeda sangat nyata. Nilai $\mathrm{C}$ organik pada tabel 2 menunjukkan peningkatan pada P2 dengan nilai $43,86 \%$, hal ini disebabkan mikroba yang berada di dalam bioaktivator yaitu mikroba lignoselulolitik berfungsi menguraikan zat organik menjadi bentuk yang lebih sederhana. Kandungan $\mathrm{C}$ organik dalam penelitian ini adalah berkisar antara 42,92\% - 43,86\% yang menunjukkan lebih tinggi dari hasil penelitian Alfadlli et al. (2018) yang menggunakan metode secara aerob. Pengaruh jumlah konsentrasi berpengaruh terhadap kinerja mikroba, pada konsentrasi sebanyak 0,5\% memiliki kandungan tertinggi dibandingkan dengan konsentrasi yang lain sehingga penggunaan bioaktivator optimal pada konsentrasi $0,5 \%$. Faktor kadar air pada penelitian ini yang tinggi selama pengomposan karena metode anaerob yang digunakan dengan memanfaatkan kinerja bakteri fakultatif, mengakibatkan timbulnya penurunan kinerja mikroba dalam mengolah kompos. Standar kualitas kompos dari parameter C Organik menurut SNI (2004) yaitu minimum 27\% dan maksimum 58\%. Kandungan $\mathrm{C}$ organik yang diperoleh dalam penelitian ini masih dalam standar yang ditetapkan SNI (2004) Penggunaan bakteri pada pengkomposan dapat bekerja pada kelembaban 40\%-60\% selebihnya atau kurang dari itu bakteri akan mengalami penurunan kinerja (Wibowo et al., 2014).

\section{Kadar Hara Makro Primer}

Hara makro yang dibutuhkan pada tanaman yaitu nitrogen $(\mathrm{N})$, fosfor $(\mathrm{P})$ dan kalium $(\mathrm{K})$. Hasil penelitian menunjukkan bahwa perbedaan level bioaktivator terhadap kandungan hara makro nitrogen pupuk kompos tidak berbeda nyata terhadap unsur nitrogen $(\mathrm{P}>0,05)$ (Tabel 2). Hal ini dikarenakan didalam bioaktivator tidak terdapat mikroba Azotobacter $s p$ dan Azospirillum $s p$ yang berfungsi dalam fiksasi nitrogen. Menurut Astari (2011) bahwa nilai kandungan nitrogen dalam kompos diperoleh dari bahan baku (feses sapi) yang digunakan dalam pembuatan kompos. Penelitian sebelumnya menyatakan penggunaan aktivator dari mol EM4 dalam pembuatan kompos berbahan dasar daun menunjukan tidak ada perbedaan yang nyata terhadap kandungan nitrogen dalam pupuk kompos yang dihasilkan menurut Widyaningrum et al. (2013).
Kandungan hara fosfor hasil penelitian ini menunjukkan bahwa perbedaan level bioaktivator sangat berbeda nyata terhadap kandungan hara makro fosfor $(\mathrm{P}<0,01)$ (tabel 2). Analisis uji lanjut diperoleh hasil P1 dan P2 dibandingkan dengan P3 dan P4. Hasil penelitian ini diperoleh nilai fosfor sebesar $0,21 \%$ sampai $0,37 \%$. Nilai kandungan hara fosfor pada penelitian ini menunjukkan nilai yang lebih tinggi dari hasil penelitian Alfadlli et al. (2018) yang dilakukan secara aerob, yaitu berkisar antara $0,10 \%-0,11 \%$. Hal ini disebabkan peran bakteri pelarut fosfat yakni BPF berperan utama penyediaan unsur fosfat, jumlah konsentrasi mempengaruhi jumlah bakteri yang berperan. Menurut Widawati dan Sulasih (2005) Bakteri Pelarut Fosfat merupakan salah satu jenis mikroba tanah yang dapat diperoleh melalui sumber eksternal yang berperan dalam penyediaan dan penyerapan unsur hara bagi tanaman. Namun, pada penelitian ini konsentrasi $0,5 \%$ memiliki kandungan paling tinggi dibandingkan konsentrasi yang lebih besar mengalami penurunan.

Hasil penelitian ini menunjukkan bahwa perbedaan level bioaktivator sangat berbeda nyata terhadap hara makro kalium $(\mathrm{P}<0,01)($ tabel 2). Analisis uji lanjut diperoleh hasil P2 dan P3 dibandingkan dengan P4 memiliki nilai berbeda sangat nyata hal ini disebabkan di dalam bioaktivator yang digunakkan sudah terdapat unsur kalium sebanyak 1,26\% sehingga berpengaruh terhadap kandungan hara pupuk kompos dan aktifitas mikroorganisme yang menggunakan kalium sebagai katalisator dalam proses fermentasi. Hal ini diperkuat oleh Hidayati (2013) yang menyatakan bahwa kalium $\left(\mathrm{K}_{2} \mathrm{O}\right)$ digunakan oleh mikroorganisme dalam bahan substrat sebagai katalisator, dengan adanya bakteri dan aktivitasnya tersebut sangat berpengaruh terhadap peningkatan kandungan kalium. Menurut Peraturan Menteri Pertanian (2011), batas minimal kandungan hara fosfor adalah $4 \%$, sehingga kandungan fosfor yang dihasilkan belum memenuhi.

\section{Kadar Hara Makro Sekunder}

Hasil penelitian menunjukkan bahwa perbedaan level bioaktivator terhadap kandungan hara mikro magnesium berbeda nyata pada pupuk kompos $(\mathrm{P}<0,05)$. Hasil analisis hara makro magnesium pada penelitian ini sebesar $0,19 \%$ - 0,29\%, hasil tersebut menunjukkan nilai yang lebih tinggi dari penelitian Alfadlli et al. (2018) yang dilakukan secara aerob sebesar $0,8 \%-0,1 \%$. Analisis uji lanjut di peroleh $\mathrm{P} 1$ dibandingkan P2 memiliki nilai naik sebesar $0,1 \%$ terhadap unsur magnesium. Hal ini disebabkan di dalam bioaktivator yang digunakan sudah terdapat magnesium sebanyak 0.15 dan ditambah dalam bahan yang digunakan mengandung unsur magnesium. Hasil penelitian ini sesuai dengan Yuwono (2007) menyatakan bahwa magnesium dapat berasal dari bahan organik, pupuk kandang dan kapur. Menurut Standar Nasional Indonesia (2004), kandungan magnesium dalam pupuk maksimal 0,60\% sehingga hasil yang diperoleh sesuai dengan standar. 


\section{Rasio C/N}

Hasil penelitian menunjukkan bahwa perbedaan level bioaktivator tidak berbeda nyata terhadap rasio $\mathrm{C} / \mathrm{N}$ pupuk kompos. Kandungan mikroorganisme di dalam probiotik yang bervariasi dalam penelitian ini tidak menyebabkan perbedaan rasio $\mathrm{C} / \mathrm{N}$ pada kompos. Penyebab lain faktor hasil nitrogen yang konstan sehingga tidak terlalu berpengaruh terhadap nilai $\mathrm{C} / \mathrm{N}$ yang dihasilkan. Sehingga memerlukan waktu yang cukup lama untuk melakukan pengomposan apabila menggunakan metode anaerob. Berdasarkan penelitian sebelumnya Alfadli et al. (2018) dalam penelitianya menggunakan metode aerob dengan waktu pengomposan selama 28 hari memiliki nilai $\mathrm{C} / \mathrm{N}$ sebesar $16 \%$ - 18\%. Rasio $\mathrm{C} / \mathrm{N}$ dalam penelitian ini lebih tinggi dari hasil penelitian yang dilakukan oleh Kusmiyarti (2013) yang menggunakan bahan feses sapi dan bioativator Bionic dengan waktu 5-9 minggu yang menghasilkan rasio $\mathrm{C} / \mathrm{N}$ sebesar 11-14. Rasio $\mathrm{C} / \mathrm{N}$ kompos dalam penelitian ini lebih tinggi dari standar SNI (2004) pupuk kompos yang berkisar antara 10\% $20 \%$. Rasio $\mathrm{C} / \mathrm{N}$ dalam penelitian ini berkisar antara $23,54 \%$ sampai $26,95 \%$.

\section{SIMPULAN}

Berdasarkan hasil penelitian dapat disimpulkan bahwa kualitas kompos yang dibuat dengan bantuan Bioaktivator dari limbah bioetanol sebagai media dengan konsentrasi yang berbeda memiliki performa terbaik pada konsentrasi $0,5 \%$.

\section{UCAPAN TERIMA KASIH}

Penelitaian ini didanai oleh Kementrian Riset, Teknologi dan Pendidikan Tinggi, Republik Indonesia pada Program Kreativitas Mahasiswa-Penelitian Eksakta (PKM-PE) dengan nomor kontrak: 547B3.1/KM/2017 dan Hibah Ipteks bagi Masyarakat Penerimaan Negara Bukan Pajak (PNBP), Universitas Sebelas Maret dengan nomor kontrak: 343/UN27/HK/2016.

\section{DAFTAR PUSTAKA}

Agus, F. dan Widianto. 2004. Konservasi tanah pertanian lahan kering. World Agroforestry Centre ICREF. Bogor.

Alfadlli, N. S., S. Noor., B. S. Hertanto and M. Cahyadi. 2018. The effect of various decomposers on quality of cattle dung compost. Buletin Peternakan 42 (3): 250-255.

Astari, L. P. 2011. Kualitas pupuk kompos bedding kuda dengan menggunakan aktivator mikroba yang berbeda. Skripsi. Fakultas Peternakan. Institut Pertanian Bogor. Bogor.

Bahar, S. dan B. Haryanto. 2000. Pembuatan kompos berbahan baku limbah ternak. Laporan bagian Proyek Teknologi Peternakan ARMP-II: 200-202.
Balai Penelitian Tanah. 2009. Petunjuk teknis analisis kimia tanah, tanaman, air, dan pupuk balai penelitian tanah, Badan Penelitian dan Pengembangan Pertanian, Departemen Pertanian. Bogor.

Ginting, N. 2007. Teknologi pengolahan limbah peternakan. Skripsi. Fakultas Pertanian Universitas Sumatera Utara. Sumatera Utara.

Hanafiah, K. A. 2005. Dasar-dasar Ilmu Tanah. Raja Garfindo Persada, Jakarta

Kesumaningwati, R. 2015. Penggunaan MOL bonggol pisang (musa paradisiaca) sebagai dekomposer untuk pengomposan tandan kosong kelapa sawit. Ziraa'ah. 40(1) : 40-45.

Kusmiyarti, T. B. 2013. Kualitas kompos dari berbagai kombinasi bahan baku limbah organik. Agrotrop: Journal on Agriculture Science 3(1) : 83-92.

Marlinda. 2015. Pengaruh penambahan bioakivator EM4 dan promi dalam pembuatan pupuk cair organik dari sampah organik rumah tangga. Skripsi. Jurusan Teknik Kimia. Politeknik Negeri Samarinda. Samarinda.

Nurcahyani, K. dan B. Utami. 2015. Pengolahan limbah cair industri alkohol bekonang menggunakan proses fermentasi. Prosiding Seminar Nasional Konservasi dan Pemanfaatan Sumber Daya Alam. Universitas Sebelas Maret. Surakarta. Indonesia pp $112-116$.

Rukmana, R. 2007. Bertanam petsai dan sawi. Kanisius. Yogyakarta. Hal: 11-35.

Sembiring, M. P. dan R. S. Irianty. 2012. Pembuatan kompos dari limbah padat (sludge) pabrik pulp dan paper. Jurnal Riset Kimia 5(1): 132-136.

Soeprijanto, T. Ismail, M. D. Lastuti, dan B. Niken. 2010, Pengolahan vinasse dari air limbah industri alkohol menjadi biogas menggunakan bioreaktor UASB. Jurnal Purifikasi 11(1): 11-20.

Standar Nasional Indonesia 19-7030-2004. 2004. Spesifikasi kompos dari sampah organik domestik. Badan Standarisasi Nasional. Bandung.

Steel, R. G. D. and J. H. Torrie. 1993. Prinsip dan prosedur statistika (pendekatan biometrik). Penerjemah B. Sumantri. Gramedia Pustaka Umum. Jakarta.

Subagyo, Y. B. P. 2008. Ilmu ternak potong dan kerja. Skripsi. Fakultas Pertanian Universitas Sebelas Maret. Surakarta.

Triwibowo, M. B., S. Suratno, dan S. A. Hesty. 2015. Pengaruh pemberian bioaktivator effective microorganism 4 (EM-4) terhadap kecepatan dan kualitas pembuatan kompos serta pemanfaatannya sebagai bahan ajar bioteknologi di SMA. Pancaran 4(2): 11-20.

Wahyono, S. F., L. Sahwan dan F. Suryanto. 2003. Mengolah sampah menjadi kompos sistem open windrow bergulir skala kawasan. Badan Pengkajian dan Penerapan Teknologi. Pusat Pengkajian dan Penerapan Teknologi. Jakarta.

Wibowo, N. A., B. E. Tjahjana, N. Heryana dan Sakiroh. 2014. Peraan mikroorganisme dalam 
pengelolaan hara terpadu pada perkebunan kakao. Bunga Rampai: Inovasi Teknologi Bioindustri Kakao. Balai Penelitian Tanaman Industri dan Penyegar. Sukabumi. p. 91-98.

Widawati, S. dan Suliasih. 2005. The application of soil microbe from wamena botanical garden as biofertilizer (compost plus) on purple eggplant (Solanum melongena L.). Jurnal Ilmiah Pertanian. Gakuryoku 11(3): 20-24.

Widyaningrum, P. dan Lisdiana. 2013. Perbedaan fisik dan kimia kompos daun yang menggunakan bioaktivator mol dan EM4. Jurnal Sain dan Teknologi. 11(1): 65-72.

Yuliarti, N dan Isroi. 2009. Kompos. C.V Andi Offset. Yogyakarta.

Yuwono, D. 2007. Kompos. Penebar Swadaya. Jakarta. 